Limnol. Rev. (2016) 16, 4: 221 - 227

DOI 10.1515/limre-2016-0024

\title{
Changes in the trophic status of lakes in the Suwałki Landscape Park (NE Poland)
}

\author{
Andrzej Górniak*, Adam Więcko, Maciej Karpowicz \\ Department of Hydrobiology, University of Białystok, Ciołkowskiego 1J, 15-254 Białystok, Poland; \\ e-mail: hydra@uwb.edu.pl (*corresponding author); a.wiecko@uwb.edu.pl; m.karpowicz@uwb.edu.pl
}

\begin{abstract}
Summer field research and chemical analyses in 2015 provided the basis for the presentation of the trophic status of waters of 28 lakes of the Suwałki Landscape Park in NE Poland, located in the catchment of the River Neman, in the Natura 2000 area - Ostoja Jeleniewska. Lakes Hańcza and Szurpiły are currently mesotrophic ecosystems. The remaining lakes are moderately eutrophic, while four lakes in the group, in addition to anaerobic hypolimnion, have infertile epilimnion similar to that of mesotrophic lakes. Lake Hańcza shows considerable multiannual dynamics of water fertility, periodically reaching a status approximate to eutrophy. In Lake Szurpiły and the majority of smaller lakes of the Suwałki Landscape Park, reduced precipitation in 2015 resulted in an inconsiderable decrease in trophic status. The lakes are under the strong influence of their catchment area, as confirmed by statistically significant correlations between TSI and the Ohle and Schindler ratios. Lakes Kluczysko and Kopane currently remain the most fertile lakes in the Park. Unless rapidly developing cattle breeding leads to excessive fertilisation of waters in the catchment, the forecasted variability of weather conditions during global climate transformations will lead to fluctuations in the fertility of the majority of the analysed lakes at the threshold of meso- and eutrophy. A hypothesis is also stated regarding the considerable role of groundwater alimentation and short retention time in the maintenance of higher than average resources of silica in limnic waters.
\end{abstract}

Key words: lakes, trophy, trophy index, phosphorous, silica, Suwałki Landscape Park

\section{Introduction}

The post-glacial lakes of Central Europe are subject to evolution, usually under a harmonious influence of environmental factors in spite of the occurrence of periodical stressors in the form of extreme climatic or hydrological events, or over the last century, human activity disturbing the character of circulation of biogene elements (Hillbricht-Ilkowska 2005). The morphometric and mictic variability of lakes together with the mosaic of vegetation of the lakeland landscape results in a temporal variability of the rate of increase in the trophic status (Zdanowski 1982).

In conditions of increasing anthropogenic eutrophication of lakes of the moderate zone, in the second half of the $20^{\text {th }}$ century, along with costly reclamation measures or changes in water management, activities aimed at limiting the unfavourable trend of changes occurring in lake ecosystems were initiated. One of the approaches was the development of new legal forms of protection of lakes together with their catchment areas in the most environmentally valuable areas.
The establishment of landscape parks commenced in Poland. Such a system of catchment management, less restrictive than in national parks, aimed to reduce the growing pressure of fishery and tourism on the lakes, and limiting the development of industry (Symonides 2007). The first Polish landscape park, established in 1976, was the Suwałki Landscape Park. Its establishment was associated with proposals to construct deep mines for metal ores $(\mathrm{Fe}, \mathrm{Ni}, \mathrm{V})$ in the area.

The assessment of the efficiency of 40 years of protection measures concerning both catchment and lakes in the landscape park is the primary objective of this paper. The assessment of the current state of the lakes involved hydrochemical analyses of waters performed in summer 2015, and earlier by the Department of Hydrobiology of the University of Białystok and other research teams. By documenting the fertility of waters, we determine the potential role of a bottom-up development of the biotic culture of the ecosystem, closely related to both local and supraregional phenomena, among which are changes of climate and atmospheric pollution. 


\section{Studied lakes}

The dominant element of the Suwałki Landscape Park is a group of 28 lakes, including Staw Turtul - an artificial lake on the River Czarna Hańcza (Table 1). They are post-glacial lakes, partly of neotectonic origin, mainly located in an extensive depression drained by the River Szeszupa (Ber 2000). Five small lakes exist on the course of the River Szeszupa in the Suwałki Landscape Park (Fig. 1). The catchment of the River Czarna Hańcza, which like the River Szeszupa belongs to the catchment of the River Neman, includes two lakes, one natural and one artificial, including the deepest lake of the Polish Lowland, namely Lake Hańcza (105.6 m in depth) (Popielarczyk et al. 2015). It is a channel lake, although the dominant type in the area are kettle lakes. Many of them occur in clusters as a result of the Holocene defragmentation of lake basins determined by spatial diversification of limnic sedimentation alternated with peat-forming processes in periods of reduced water levels in lakes (Lauterbach et al. 2011). The number of closed-drainage, flow-through, and drainage lakes in the Park is approximate, while many lakes have been artificially incorporated into the surface water network through systems of melioration ditches. Due to the morphometric diversity of lakes of the young glacial landscape with cratonic distribution of groundwaters, the groundwater alimentation of part of the lakes with various surface areas constitutes an important element of the water balance (BajkiewiczGrabowska 2002). This contributes to the variability of water stages in the multiannual and annual cycle (Górniak and Piekarski 2002), variable matter circulation, and development of rarely encountered assemblages of plants, plankton, benthos, or structure of the nekton (Hillbricht-Ilkowska 1994; Zdanowski et al. 2008). Moreover, the long settlement tradition of the region, including the settlement of the Yotvingians at

Table 1. Range of water parameters in the epilimnion of lakes in the Suwałki Landscape Park in 2003 (Górniak et al. 2006) and in 2015 (recent study)

\begin{tabular}{|c|c|c|c|c|c|}
\hline \multirow{2}{*}{ Parameter } & \multirow{2}{*}{ Units } & \multicolumn{2}{|c|}{2003} & \multicolumn{2}{|c|}{2015} \\
\hline & & $\min$ & $\max$ & $\min$ & $\max$ \\
\hline Secchi Disc & $\mathrm{m}$ & 0.7 & 6.4 & 1.0 & 5.95 \\
\hline $\mathrm{pH}$ & - & 6.5 & 8.4 & 7.4 & 8.3 \\
\hline oxygen & $\%$ & 72 & 268 & 81 & 138 \\
\hline EC & $\mu S \mathrm{~cm}^{-1}$ & 147 & 665 & 139 & 505 \\
\hline TP & $\mu \mathrm{g} P \mathrm{dm}^{-3}$ & 96 & 513 & 49 & 155 \\
\hline $\mathrm{N}-\mathrm{NH}_{4}$ & $\mu \mathrm{g} \mathrm{N} \mathrm{dm^{-3 }}$ & 139 & 460 & 1.0 & 216 \\
\hline $\mathrm{N}-\mathrm{NO}_{3}$ & $\mu \mathrm{g} \mathrm{N} \mathrm{dm^{-3 }}$ & 0.0 & 66 & 0.5 & 212 \\
\hline $\mathrm{Si}$ & $\mathrm{mg} \mathrm{dm}^{-3}$ & 0.2 & 7.0 & 0.2 & 1.88 \\
\hline Chlorophyll-a & $\mu \mathrm{g} \mathrm{dm}-3$ & 0.4 & 17.2 & 0.5 & 49.5 \\
\hline
\end{tabular}
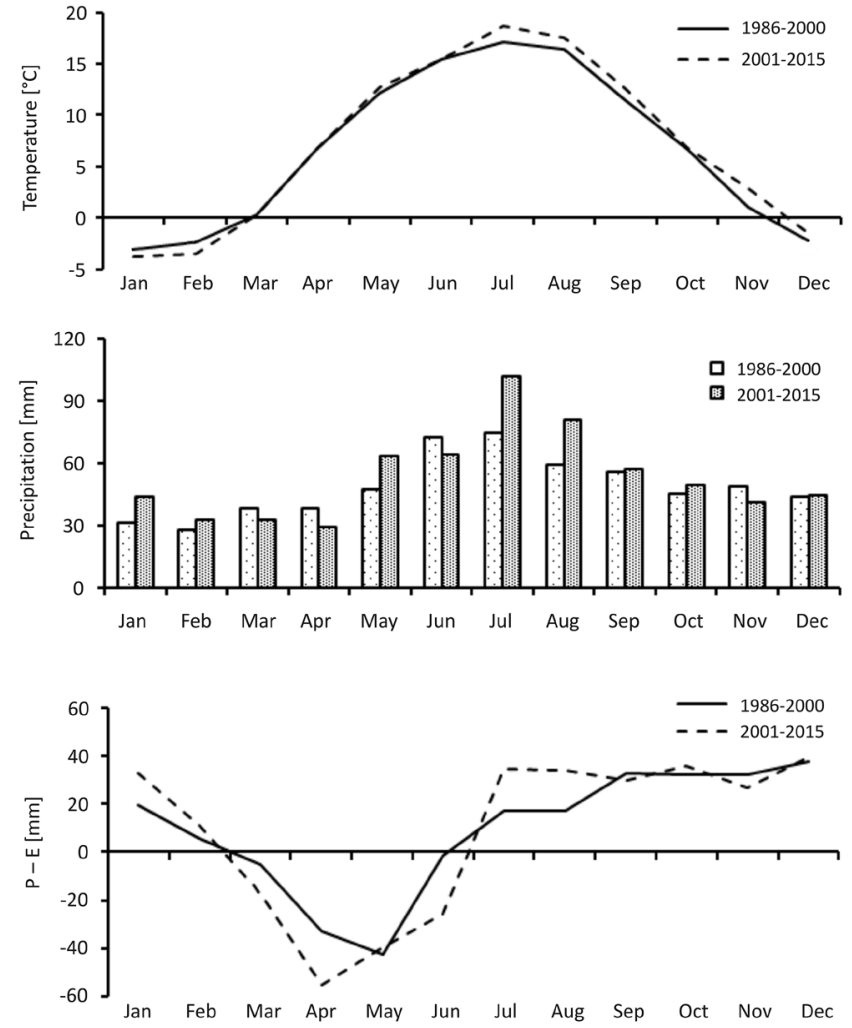

Fig. 1. Seasonal changes of selected climate parameters in NE Poland in the years 1986-2015 (data for Suwałki, located close to SLP)

the end of the Middle Ages (Engel 2016), resulted in changes in the forest cover of the catchment, leading to transformations of the fluvial-limnic system, currently distinguished by its relatively natural character (Hillbricht-Ilkowska 1990).

Besides its geological structure, the Suwałki Landscape Park is distinguished by the lowest mean air temperature in the lowland part of Poland, and evident pluvial continentalism of the climate (Górniak 2006). In the context of the global climatic changes of the last 15 years (2001-2015), an increase in the mean annual temperature and the summer period was recorded in comparison to the period 1986-2000. A higher than average mean precipitation total in July and August, as

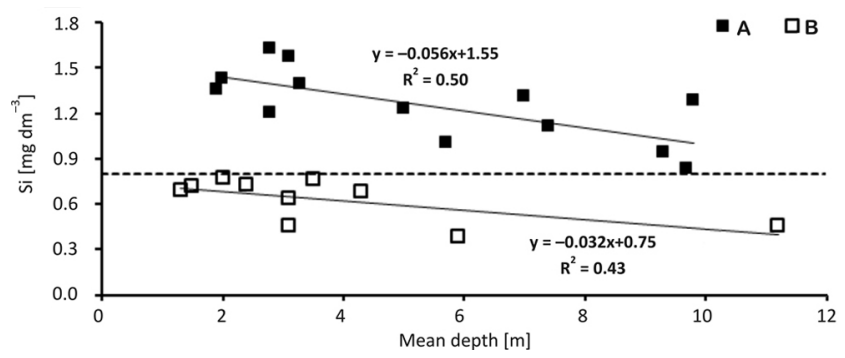

Fig. 2. Correlation between mean lake depth and epilimnion Si concentration in summer 2015. A and B - groups of lakes 
Table 2. Summer (July/August) epilimnion data and oxygen presence near the bottom of deep $\left(z_{\max }>10 \mathrm{~m}\right)$ lakes in the Suwałki Landscape Park in 2015. Explanation: $z_{\max }$ - maximum depth, EC - specific conductivity, SD - Secchi disc depth, TP - total phosphorous, TN - total nitrogen, TOC - total organic carbon, $\mathrm{Si}-$ silica. Lake area and maximum depth according to Borowiak et al. 2016. Oxygen: + present in the hypolimnion, - absent in the hypolimnion

\begin{tabular}{|c|c|c|c|c|c|c|c|c|c|}
\hline Lake & Area [ha] & $z_{\text {max }}[\mathrm{m}]$ & $\mathrm{EC}\left[\mu \mathrm{S} \mathrm{cm^{-1 } ]}\right.$ & $\mathrm{SD}[\mathrm{cm}]$ & $\mathrm{TP}\left[\mathrm{mg} \mathrm{dm}^{-3}\right]$ & $\mathrm{TN}\left[\mathrm{mg} \mathrm{dm}^{-3}\right]$ & TOC [mg dm $\left.{ }^{-3}\right]$ & $\mathrm{Si}\left[\mathrm{mg} \mathrm{dm}^{-3}\right]$ & Oxygen \\
\hline Hańcza & 303.6 & 105.6 & 275 & 420 & 0.091 & 0.54 & 4.99 & 0.18 & + \\
\hline Jaczno & 40.6 & 25.7 & 433 & 290 & 0.054 & 0.18 & 2.77 & 1.28 & - \\
\hline Jeglówek & 20.1 & 27.7 & 337 & 595 & 0.054 & 0.49 & 5.99 & 0.94 & - \\
\hline Kamenduł & 25.3 & 26.2 & 426 & 250 & 0.091 & 0.24 & 3.14 & 1.31 & - \\
\hline Kluczysko & 3.7 & 13.8 & 328 & nd & 0.125 & 0.59 & 7.12 & 1.89 & - \\
\hline Kojle & 17.3 & 32.3 & 363 & 440 & 0.054 & 0.30 & 4.08 & 0.83 & - \\
\hline Kopane & 16.2 & 18.8 & 342 & 120 & 0.061 & 0.47 & 6.15 & 1.00 & - \\
\hline Perty & 19.5 & 32.6 & 354 & 490 & 0.061 & 0.30 & 4.75 & 1.11 & - \\
\hline Pogorzałek & 5.8 & 17.6 & 186 & 160 & 0.064 & 0.45 & 7.28 & 0.39 & - \\
\hline Szurpiły & 84.3 & 47.1 & 349 & 290 & 0.061 & 0.39 & 4.27 & 0.46 & + \\
\hline
\end{tabular}

well as an early spring shortage of water resources in the catchment is magnified, as evidenced by the negative value of the difference between precipitation and evapotranspiration (Fig. 2). The summer of 2015, when the field research was performed, was distinguished by high air temperature. Precipitation was considerably lower than the mean multiannual value, with signs of hydrological drought.

\section{Methods}

Field research on 28 lakes of the Suwałki Landscape Park was undertaken in July and August 2015. Field measurements included Secchi disc visibility, electrometric measurements of electrolytic conductivity, temperature, $\mathrm{pH}$, and oxygen concentration by means of HAACH sensors in the lake's profile. Water samples for chemical analyses were collected from three layers, namely the epi-, meta-, and hypolimnion. In shallow lakes, a single sample was collected from the surface $1.5 \mathrm{~m}$ water layer, usually outside the emergent plant zones. In the laboratory of the University of Białystok, on the same day, total nitrogen was analysed by means of a Shimatzu analyser, total phosphorus after mineralisation by the spectrometric method, and chlorophyll a after extraction with hot ethanol by means of a GF/C filter with plankton. The study also used data obtained in 2003 from research with a similar scope (Górniak et al. 2007), archival data of the Department of Hydrobiology of the University of Białystok, and hydrochemical data from communications and studies of the Voivodship Inspectorate of Environmental Protection concerning the studied lakes in 2010 and before 2003. Climatic data from the period 1986-2000 were obtained from a paper by Górniak (2006), and meteorological data for Suwałki station, available on www.tutiempo. net. Trophic indices were calculated in accordance with formulas proposed by Carlson (1977), Kratzer and Brezonik (1981) and Dunalska (2011).

\section{Results}

The lakes of the Suwałki Landscape Park have a variable chemical composition of waters. Particularly soft lakes are encountered here, with conductivity below $200 \mu \mathrm{S} \mathrm{cm}^{-1}$ (Boczniel, Pogorzałek), as well as lakes with waters with considerable hardness with an EC of approximately $500 \mu \mathrm{S} \mathrm{cm}^{-1}$ (Purwin, Purwinek, Łuśnin) (Table 1). In the epilimnion of deep lakes with summer thermal stratification of waters, EC values are lower by $20-60 \mu \mathrm{S} \mathrm{cm}^{-1}$ than in the meta- and hypolimnion. The waters have a slightly alkaline or neutral reaction. The surface water layers in the lakes are aerated. Oxygen is present only in the hypolimnion of two lakes (Hańcza, Szurpily). In the remaining lakes, the near-bottom layers are devoid of oxygen (Table 2). The presence of nutrients $(\mathrm{N}, \mathrm{P}, \mathrm{Si})$ is variable in the lakes, although the concentrations of N-NO, $\mathrm{N}_{3} \mathrm{NH}_{4}$ and TP were moderately low in both deep (Table 2) and shallow lakes (Table 3). Only in four out of the 28 studied lakes of the Suwałki Landscape Park were TP concentrations higher than $0.1 \mathrm{mg} \mathrm{P} \mathrm{dm}^{-3}$, and TN concentrations were always lower than $1 \mathrm{mg} \mathrm{N} \mathrm{dm}^{-3}$. The presence of organic carbon compounds (TOC) in the photic layer of the analysed lakes did not exceed $10 \mathrm{mg} \mathrm{C} \mathrm{dm}{ }^{-3}$. Concentrations of dissolved silica in the waters of the epilimnion varied in a wide range from 0.18 to $1.9 \mathrm{mg} \mathrm{dm}^{-3}$, whereas a statistically significant correlation exists involving a decrease in the concentrations with an increase in the mean depth in two groups of lakes with a threshold concentration of $0.8 \mathrm{mg} \mathrm{dm}^{-3}$ (Fig. 2).

A statistically significant inversely proportional correlation was also recorded between mean depth of the lakes and Si concentration, but in two groups of lakes differing in hydrological terms (Fig. 2). Only the six deepest lakes of the Suwałki Landscape Park are characterised by values of the Carlson trophy indices (1977) below 50, typical of mesotrophy. For the remaining lakes, the values suggest eutrophic status (Table 4). 
Table 3. Summer (July/August) data for surface water layer of shallow lakes in the Suwałki Landscape Park in 2015. Explanation: $z_{\max }-$ maximum depth, EC - specific conductivity, TP - total phosphorous, TN - total nitrogen, TOC - total organic carbon, Si - silica. Lake area and maximum depth according to Borowiak et al. 2016

\begin{tabular}{|c|c|c|c|c|c|c|c|}
\hline Lake & $\begin{array}{c}\text { Area } \\
\text { [ha] }\end{array}$ & $\begin{array}{l}z_{\max } \\
{[\mathrm{m}]}\end{array}$ & $\begin{array}{c}\mathrm{EC} \\
{\left[\mu \mathrm{S} \mathrm{cm}^{-1}\right]}\end{array}$ & $\begin{array}{c}\mathrm{TP} \\
{\left[\mathrm{mg} \mathrm{dm}^{-3}\right]}\end{array}$ & $\begin{array}{c}\mathrm{TN} \\
{\left[\mathrm{mg} \mathrm{dm}^{-3}\right]}\end{array}$ & $\begin{array}{c}\mathrm{TOC} \\
{\left[\mathrm{mg} \mathrm{dm}^{-3}\right]}\end{array}$ & $\begin{array}{c}\mathrm{Si} \\
{\left[\mathrm{mg} \mathrm{dm}^{-3}\right]}\end{array}$ \\
\hline Boczniel & 19.2 & 3.9 & 139 & 0.071 & 0.49 & 8.23 & 0.69 \\
\hline Gulbin & 7.4 & 9.1 & 436 & 0.090 & 0.42 & 4.39 & 0.77 \\
\hline Jeglóweczek & 1.8 & 8.3 & 250 & 0.049 & 0.54 & 7.33 & 0.46 \\
\hline Krajwelek & 8.8 & 5.5 & 434 & 0.047 & 0.48 & 4.50 & 1.20 \\
\hline Linówek & 2.9 & 5.9 & 246 & 0.091 & 0.56 & 7.56 & 0.73 \\
\hline Łuśnin & 0.5 & 3.0 & 505 & 0.101 & 0.39 & 4.26 & 0.28 \\
\hline Muliste & 2.7 & 4.8 & 393 & 0.155 & 0.73 & 9.40 & 1.36 \\
\hline Okrągłe & 15.0 & 7.4 & 440 & 0.064 & 0.43 & 4.54 & 0.68 \\
\hline Postawelek & 3.4 & 4.0 & 447 & 0.068 & 0.37 & 4.58 & 0.64 \\
\hline Przechodnie & 23.9 & 5.4 & 410 & 0.061 & 0.46 & 5.92 & 1.63 \\
\hline Purwin & 1.4 & 4.3 & 503 & 0.061 & 0.45 & 5.53 & 0.72 \\
\hline Purwinek & 0.4 & 3.3 & 502 & 0.152 & 0.25 & 3.53 & 0.77 \\
\hline Snołda & 0.5 & 4.5 & 452 & 0.057 & 0.38 & 5.36 & 1.43 \\
\hline Ślepak & 1.2 & $>7.0$ & 407 & 0.088 & 0.25 & 3.20 & 1.23 \\
\hline Udziejek & 7.0 & 6.9 & 363 & 0.061 & 0.51 & 5.27 & 1.39 \\
\hline Wodziłki & 3.7 & 5.4 & 480 & 0.054 & 0.45 & 5.90 & 1.57 \\
\hline Staw Turtul & 4.0 & 3.5 & 359 & 0.098 & 0.39 & 5.28 & 0.54 \\
\hline
\end{tabular}

Table 4. Trophy state index for lakes of the Suwałki Landscape Park in 2003 (according to Górniak et al. 2006) and 2015 - this study. Trophy index for Secchi disc, chlorophyll- $a$, TP according to Carlson (1977), for TN according to Kratzer and Brezonik (1981), and for TOC according to Dunalska (2011)

\begin{tabular}{lccc}
\hline \multicolumn{1}{c}{ Lakes } & TSI (SD, Chl, TP) & TSI (TN) & TSI(TOC) \\
\hline Boczniel & 50.3 & 44.2 & 53.7 \\
\hline Gulbin & 57.9 & 42.0 & 43.8 \\
\hline Hańcza & 47.1 & 45.6 & 45.8 \\
\hline Jaczno & 45.6 & 29.8 & 36.6 \\
\hline Jeglóweczek & 51.4 & 45.4 & 51.9 \\
\hline Jeglówek & 44.8 & 44.2 & 48.7 \\
\hline Kamenduł & 52.0 & 33.7 & 38.6 \\
\hline Kluczysko & 66.7 & 46.8 & 51.4 \\
\hline Kojle & 44.7 & 37.3 & 42.7 \\
\hline Kopane & 58.9 & 43.5 & 49.1 \\
\hline Krejwelek & 56.5 & 43.7 & 44.2 \\
\hline Linówek & 56.1 & 46.0 & 52.4 \\
\hline Łuśnin & 58.0 & 40.9 & 43.4 \\
\hline Muliste & 50.3 & 49.9 & 44.4 \\
\hline Okrągłe & 56.2 & 42.3 & 45.1 \\
\hline Perty & 44.6 & 37.2 & 52.4 \\
\hline Pogorzałek & 57.1 & 43.0 & 51.8 \\
\hline Postawelek & 55.0 & 40.0 & 44.5 \\
\hline Purwin & 56.8 & 42.8 & 47.5 \\
\hline Purwinek & 60.2 & 34.6 & 40.4 \\
\hline Przechodnie & 53.0 & 43.1 & 48.5 \\
\hline Snołda & 52.3 & 40.4 & 47.0 \\
\hline Szurpiły & 49.9 & 41.0 & 43.4 \\
\hline Ślepak & 53.2 & 34.4 & 38.9 \\
\hline Udziejek & 58.6 & 44.6 & 46.7 \\
\hline Wodziłki & 53.1 & 43.1 & 48.5 \\
\hline Staw Turtul & 52.3 & 41.0 & 46.7 \\
\hline & & & \\
\hline
\end{tabular}

The maximum TSI value was recorded in Lakes Kluczysko and Kopane in the catchment of the Szurpiłka Stream. The TSI values, calculated based on TN concentrations, are considerably lower than TSI values according to Carlson (1977) and calculated for TOC (after Dunalska 2011). TSI(TN) values show a statistically significant correlation $(\mathrm{r}=0.71, \mathrm{p}<0.005)$ with TSI(TOC), while no significant statistical correlation is observed between either of the indices and TSI accor ding to Carlson. In Lakes Perty and Boczniel, TSI(TOC) values are higher than TSI according to Carlson, suggesting a higher than average abundance of organic matter in the waters (Table 4).

\section{Discussion}

In the area of the Suwałki Landscape Park, only the two largest Lakes, Hańcza and Szurpily, are of mesotrophic character. The remaining 25 natural lakes belong to a group of eutrophic lakes. The summer epilimnion of four deep lakes $\left(z_{\max }>25 \mathrm{~m}\right)$ in the Park such as Lake Jaczno, Jeglówek, Kojle, and Perty, show low fertility typical of mesotrophic lakes (TSI 44-48), although the hypolimnion of the lakes is entirely devoid of oxygen, and in the context of the OECD classification (Vollenweider 1989), this evidently suggests that their character is eutrophic. The low productivity of the epilimnion in the said four eutrophic lakes has been maintained over a considerable period (Table 5), and in the 1980's small amounts of oxygen were recorded above the bottom of Lake Jeglówek (Hillbricht-Ilkowska 1990). Moreover, the high ratio of TN:TP amounting 
Table 5. Long-term changes of Carlson's trophy index (TSI) for selected lakes in the Suwałki Landscape Park between 1983 and 2015; trophy index according to Carlson (1977) and calculated based on data for TP, TN, and Secchi disc depth. Data 1 - Hillbricht-Ilkowska 1994, 2 - Górniak et al. (2006), 3 - Jekatierynczuk-Rudczyk et al. 2014, 4 - this study, n.d. - lack of data

\begin{tabular}{lcccc}
\hline \multicolumn{1}{c}{ Lake } & $1983 / 1985^{1}$ & $2003^{2}$ & $2009^{3}$ & $2015^{4}$ \\
\hline Szurpiły & 41 & 59 & 54 & 50 \\
\hline Kamenduł & 54 & 56 & 55 & 52 \\
\hline Perty & 37 & 43 & 40 & 45 \\
\hline Jeglówek & 39 & 52 & 44 & 45 \\
\hline Kojle & 44 & 52 & 54 & 45 \\
\hline Przechodnie & 59 & n.d. & 60 & 53 \\
\hline Okrągłe & 57 & n.d. & 61 & 56 \\
\hline Krajwelek & 61 & 61 & 62 & 56 \\
\hline Kluczysko & 46 & 70 & n.d. & 67 \\
\hline Kopane & 49 & 61 & n.d. & 59 \\
\hline Udziejek & 59 & 64 & 63 & 59 \\
\hline Pogorzałek & n.d. & 60 & 66 & 57 \\
\hline Linówek & n.d. & 53 & 51 & 37 \\
\hline
\end{tabular}

to more than 20 in the lakes suggested that plankton productivity is limited by phosphorus. The N:P values in the epilimnion of the lakes of the Suwałki Landscape Park are currently lower (4-8). This suggests an increase in the availability of phosphorus for algae as a result of slow eutrophication of lakes. Only in Lakes Jeglóweczek and Krajwelek, does the value of the N:P ratio slightly exceed value 10 , documenting optimum habitat conditions for the development of algae. Lake Linówek, with catchment features typical of dystrophic lakes, currently has the character of a harmonious lake in hydrochemical terms. It can be described as humoeutrophic (Górniak 1996). Staw Turtul, constituting an artificial lake on the River Czarna Hańcza recorded on maps from as long ago as the $18^{\text {th }}$ century, also has features of a moderately eutrophic lake.

The recorded hydrochemical status of the lakes of the Suwałki Landscape Park in 2015 and comparison with previous research shows that for the majority of the lakes, the state of fertility has been subject to slight

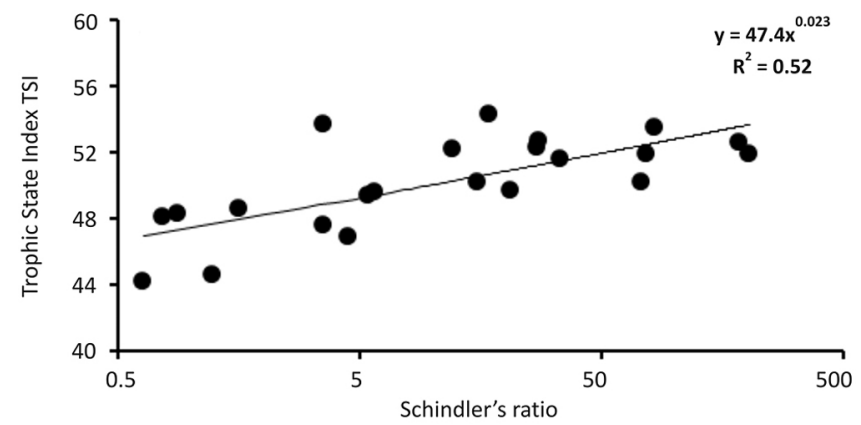

Fig. 3. Correlation between Schindler's ratio and Carlson's TSI (calculated from TP and chlorophyll- $a$ in 2015) for lakes in the Suwałki Landscape Park changes over the last 30 years, with periodical fluctuations with low amplitude of the trophy index. In summer 2015 a decrease in the trophic status was recorded in in the majority of the lakes in comparison to research from 2003 and 2009 (Table 5). One reason for this fall was the exceptionally warm and dry summer of that year, which reduced the catchment inflow of the biogene load. This is of great importance for the lakes of the Park, where the role of the catchment in the development of trophic status is considerable. This is confirmed by the statistically significant, directly proportional correlation between the Schindler ratio (ratio of the surface area of the catchment to the lake's volume) and TSI (Fig. 3). Additionally, the Ohle ratio (ratio of the surface area of the catchment to the lake) turns out to be important for the development of the trophic status of the lakes of the Suwałki Landscape Park. It is described by the following linear correlation: TSI $=1.794$ $\ln (\mathrm{A})+47.2$, where $\mathrm{A}$ is the value of the Ohle ratio $\left(\mathrm{r}^{2}=\right.$ $0.55, \mathrm{p}<0.001)$. Therefore, the discussed group of lakes in the case of the occurring periods of spring or summer drought will show a decrease in trophic status, and higher than average humidity of the vegetative season will be accompanied by an increase in lake trophy.

The presented response of lakes to variable hydroclimatic conditions of the catchment would seem to be probable for smaller and medium-sized lakes, as indicated by Bajkiewicz-Grabowska (2002). In Lake Hańcza, the documented changes of the trophic status from 1984 suggest a broad range of variability from oligotrophy to eutrophy, with dominant mesotrophic status (Fig. 4). The multiannual dynamics of fertility of the lake's waters results in changes in the structure of phytoplankton which is the fastest to respond to any manifestations of hydrochemical stress. During the highest increase in the lake's trophy in 2007 (TSI $=50.4$ ), a diatom-cyanobacterial assemblage of planktonic algae was recorded, different to those occurring in infertile lowland lakes (diatom-cryptophytic) (Hutorowicz and Napiórkowska-Krzebietke 2008). Data from

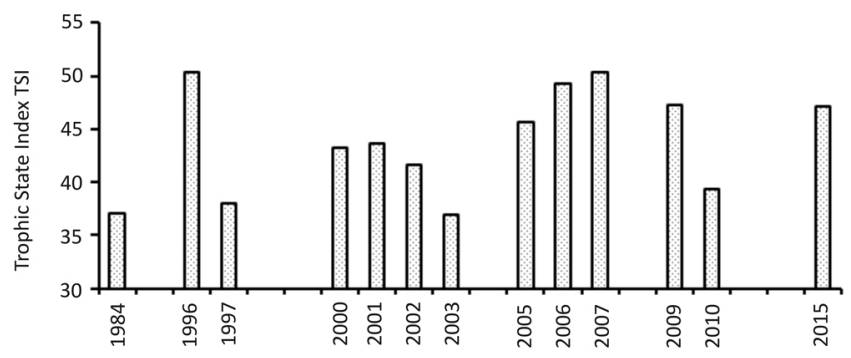

Fig. 4. Long-term changes of Trophic State Index (according to Carlson (1977)) in Lake Hańcza; data from 1984 to 2007 collected by Zdanowski et al. 2008, data 2009 from Jekatierynczuk-Rudczyk et al. 2014, data 2010 from Voiv. Inspect. Environ. Protec. in Białystok, 2015 - this study 
2015 document the presence of a diatom-chlorophyticcryptophytic assemblage (Karpowicz et al. 2016). This suggests an increase in the abundance of nitrogen in the waters. A lengthy period of water retention time in the lake, high hydrochemical inertia of deep lakes, and good oxygenation of the hypolimnion make the occurrence of the phenomenon of internal supply of biogenes contained in sediments to the lake's waters impossible. Therefore, the low trophic status of the lake can be maintained, unless the recently developing cattle breeding activities in the catchment area lead to excessive fertilisation of rivers, particularly by organic nitrogen compounds, as documented in the neighbouring catchment of the River Szeszupa (Górniak 2016).

New and important information regarding the lakes of the Suwałki Landscape Park obtained during research in 2015 document the existence of two groups of lakes with similar morphological parameters of their lake basins, but different $\mathrm{Si}$ concentrations in summer epilimnion (Fig. 2). The detailed analysis of both groups of lakes and the abiotic parameters of the catchment reveals the important role of the hydrological factor in the development of the variability of $\mathrm{Si}$ concentrations in waters. Lakes with Si concentrations lower than $0.8 \mathrm{mg}$ $\mathrm{dm}^{-3}$ (like B group in Fig. 2) belong to the group with long retention time, often closed-drainage lakes, where development of algae, and particularly diatoms, leads to gradual exhaustion of $\mathrm{Si}$ resources. Lakes with $\mathrm{Si}$ concentrations of more than $0.8 \mathrm{mg} \mathrm{dm}^{-3}$ in 2015 (like group A in Fig. 2) are characterised by an increased rate of water exchange, or considerable groundwater alimentation. Groundwaters circulating in silicate postglacial sediments and riverine waters contain considerable amounts of this element (Mazurek 2008). Therefore, short period of limnic retention or existence of groundwater inflow ensures its increased presence in lakes. Lack of direct groundwater alimentation of lakes and its utilisation mainly by phytoplankton results in a substantial reduction of dissolved Si concentrations, particularly evident in rivers flowing through lakes or artificial dam reservoirs (Conley and Struyf 2010). The basic hypothesis on the importance of groundwater alimentation in the development of silica resources in lake waters requires further investigation and field research with a higher degree of detail.

\section{References}

Bajkiewicz-Grabowska E., 2002, Obieg materii w ekosystemach rzeczno-jeziornych (Circulation of matter in riverlake ecosystems), Wydaw. UW, Warszawa, 274 pp. (in Polish, English summary).

Ber A., 2000, Plejstocen Polski północno-wschodniej w nawiązaniu do głębszego podłoża i obszarów sąsiednich
(Pleistocene of north-eastern Poland and neighbouring areas against crystalline and sedimentary basement), Pr. PIG 170: 1-89. (in Polish, English summary).

Borowiak D., Nowiński K., Grabowska K., 2016, A new bathymetric survey of the Suwałki Landscape Park lakes, Limnol. Rev. 16(4): 185-197.

Carlson R.E.,1977, A trophic state index for lakes, Limnol. Oceanogr. 22(2): 361-369.

Conley D.J., Struyf E., 2010, Silica, [in:] Likens G.E. (ed.), Biogeochemistry of inland waters, Academy Press, Amsterdam: 414-417.

Dunalska J., 2011, Total organic carbon as a new index for monitoring trophic states in lakes, Oceanol. Hydrobiol. Stud. 40(2): 112-115.

Engel M., 2016, 440 years of research on early medival Yatving (Sudovian) Archeology, [in:] Yatving Archeology. Past research, New perspectives, Wydaw. PMA, Warszawa: 11-71.

Górniak A., 1996, Substancje humusowe i ich rola w funkcjonowaniu ekosystemów słodkowodnych (Humus substances and their role in the freshwater ecosystems functioning), Diss.Univ.Vars. 445, Wydaw. UW, Warszawa, 151 pp. (in Polish).

Górniak A., 2006, Klimat województwa podlaskiego (Climate of Podlaskie Voivodeship), IMGW, Warszawa, 119 pp.(in Polish).

Górniak A., 2016, Export of nutrients from the catchment of the upper Szeszupa River (drainage basin of the Neman River) and its seasonality, Limnol. Rev. 16(4): 213-219.

Górniak A., Szumieluk D., Zielinski P., Suchowolec T., Jekatierynczuk-Rudczyk E., 2007, jeziora Suwalskiego Parku Krajobrazowego - aktualna trofia i jakość wód (Lakes of the Suwałki Landscape Park - current trophy and water quality), Mat. Konf. „Parki krajobrazowe w krajowym systemie ochrony obszarowej”, Szelment 28-29 września 2006, Turtul, 31-36 (in Polish).

Górniak A., Piekarski K., 2002, Seasonal and multiannual changes of water level in lakes of Northeastern Poland, Pol. J. Environ. Stud. 11(4):349-354.

Hillbricht-Ilkowska A., 1990, Factors responsible for retarding the eutrophication rate of some mesotrophic lowland lakes in N.E. Poland, Int. Revue Gesam. Hydrobiol. 75(4): 447-459.

Hillbricht-Ilkowska A., 1994, Ocena ładunku fosforu i stanu zagrożenia jezior Suwalskiego Parku Krajobrazowego oraz niektóre zależności pomiędzy ładunkiem a wskaźnikiem trofii jezior (Evaluation of the phosphorus load and degree of endangerment, of lakes in Suwałki Landscape Park, and some relationhips between the load and the indices of the status of lakes), [in:] HillbrichtIlkowska A., Wiśniewski R.J. (eds) Jeziora Suwalskiego Parku Krajobrazowego. Związki z krajobrazem, stan eutrofizacji i kierunki ochrony (Lakes of the Suwałki Landscape Park. Links with landscape, eutrophication and protection measures), Zesz. Nauk. Kom. Nauk. PAN 
„Człowiek i Środowisko” 7: 201-214 (in Polish, English summary).

Hillbricht-Ilkowska A., 2005, Ochrona jezior i krajobrazu pojeziernego - problem, procesy, perspektywy (Protection of lakes and lakelands - problems, processes, perspectives), Kosmos 54(2-3): 285-302 (in Polish, English summary).

Hutorowicz A., Napiórkowska-Krzebietke A.,2008, Zbiorowiska fitoplanktonu w jeziorze Hańcza (Phytoplanktom communities in Hańcza Lake), [in:] Kozłowski J., Poczyński P., Zdanowski B. (eds), Środowisko i ichtiofauna jeziora Hańcza (Enironment and ichtiofauna of Lake Hańcza) Wydaw. IRS, Olsztyn: 93-102 (in Polish).

Jekatierynczuk-Rudczyk E., Zieliński P., Grabowska M., Ejsmont-Karabin J., Karpowicz M., Więcko A., 2014,The trophic status of Suwałki Landscape Park lakes based on selected parameters (NEPoland), Environ. Monit. Assess. 186(8): 5101-5121.

Karpowicz M., Górniak A., Więcko A., Cudowski A., 2016, The variability of summer phytoplankton communities in different types of lakes in Suwałki Landscape Park, Limnol. Rev. 16(4): 229-236.

Kratzer C.R., Brezonik P.L., 1981, A Carlson-type trophic state index for nitrogen in Florida lakes, Water Res. Bull. 17(4): 713-715.

Lauterbach S., Brauer A., Andersen N., Danielpol D.L., Dulski P., Hüls M., Milecka K., Namiotko T., Plessen B., von Grafenstein U., DecLakes participants 2011, Multi-proxy evidence for early and mid-Holocene environmental and climatic changes in northeastern Poland, Boreas 40: 5772 .

Mazurek M., 2008, Czynniki kształtujące skład chemiczny wypływów wód podziemnych w południowej części dorzecza Parsęty (Pomorze Zachodnie) (Factors affecting the chemical composition of groundwater outflows in the southern part of Parsęta drainage basin (Western Pomerania), Prz..Geol. 56(2): 131-139 (in Polish, English summary).

Popielarczyk D., Templin T., Łopata M., 2015, Using the geodetic and hydroacoustic measurements to investigate the bathymetric and morphometric parameters of Lake Hancza (Poland), Open Geosci. 7: 854-869.

Symonides E., 2007, Ochrona przyrody (Nature protection), Wydaw. UW, Warszawa, 767 pp. (in Polish).

Vollenweider R., 1989, Global problems of eutrophication and its control, Symp. Biol. Hung. 38: 19-41.

Zdanowski B.,1982, Nitrogen and phosphorous in lakes and their eutrophication, Pol. Arch. Hydrobiol, 29(3-4): 541597.

Zdanowski B., Stawecki K., Pyka J.P., 2008, Środowisko abiotyczne jeziora Hańcza (Abiotic environment of Lake Hańcza), [in:] Kozłowski J., Poczyński P., Zdanowski B. (eds), Srodowisko i ichtiofauna jeziora Hańcza (Environment and ichtiofauna of Lake Hańcza), Wydaw. IRS, Olsztyn: 59-73 (in Polish). 